\title{
Farm monitoring to futures contracts: The Hannas' experience
}

\author{
A.B. HANNA ${ }^{1}$, A.M. HANNA ${ }^{1}$ and R.W. WEBBY ${ }^{2}$ \\ ${ }^{1}$ Mahoenui, RD, Te Kuiti \\ ${ }^{2}$ AgResearch Ruakura, Private Bag 3123, Hamilton
}

\begin{abstract}
Being part of a group farm monitoring project and then a farm systems study has enabled the Hannas to develop their farm business to where they can supply livestock to meat processors under futures contract arrangements. The recognition and development of farm-monitoring protocols has enabled them to identify key weight and weight gain targets. A database of weights, pasture growth and pasture cover information has enabled them to predict numbers, weights and supply times. The result of this farm monitoring has been a $35 \%$ increase in productivity over the past 5 years. Lambing \% has increased from 112 to $146 \%$ survival to sale. Bull beef cattle numbers have increased by $430 \%$ as the area suitable for running them has been fenced and developed. The Hannas have classified their land into capability units and farm these units accordingly. They recognise the strong link between farming profitably and sustainably and believe that the demonstration of sustainable farming practices will be a requirement to enter into high value markets in the future. Winning of the supreme Waikato Farm Environment award in 1999 was a reflection of this philosophy.
\end{abstract}

Keywords: bull beef, futures contracts, monitor farm, sustainability

\section{Introduction}

Fixed price futures contracts for supplying sheep and beef cattle for slaughter are now commonplace within the industry. The ability to accurately predict the number of animals that comply to weight specifications for future supply has many advantages for a farmer. Not only to fulfil contracts but also for booking killing space for peak season periods. This paper looks at the processes and systems one farmer and a farm study group (Sheath et al. 1999) used to improve farm profitability and to position themselves to meet future supply contracts. It covers a history of involvement in group farm monitoring and farm study groups and highlights the link between farming profitably and sustainably.
The Northern King Country Farm Study Group started with a group farm monitoring programme on Barrie and Jude Tatham's farm at Pio Pio in February 1992 (Webby and Paine 1997). In 1995, after finishing the 3 years at Tathams, the group decided to take on a more in-depth programme. They sought a full commitment from all the members involved and required all farmers to carry out their own monitoring.

To improve the long-term financial performance on all the farms involved, the group members needed to develop a farm system where they could increase productivity and consistently meet forecast sale dates with the correct weight and quality of product. They needed to understand their farm systems so they could develop the flexibility to meet changing markets.

\section{The study group}

The main aims of the Northern King Country Farm Study Group were to assist members to increase profit, improve farm productivity and identify management practices which improve product quality. This involved objective on-farm monitoring systems such as stock weighing, pasture covers and pasture growth rates in order to make the correct management decisions (Webby and Sheath 1991). With these aims in mind, the group undertook a project that would enable members to use a decision support model that would assist them in meeting market requirements for beef and lamb that can change yearly and seasonally. Furthermore, the project was to help position group members as recognised suppliers of quality beef cattle and lamb that would enable them to sell on the basis of a quality product, rather than as a commodity on the spot market. As a key component to help understand and learn about their farm systems, group members trained in the use of Stockpol (Marshall et al. 1991).

The group required a farm that would provide a central focus and context for their study. They selected Brian and Andrea Hannas farm, "Rauroa", a 450effective-ha sheep and beef cattle farm at Mahoenui in the King Country. Brian and Andrea were in a development phase and were in a good position to benefit from the focus of the group. Equally, group members would benefit from being able to follow and observe the changes on the Hanna farm. 


\section{Description of the Hanna farm}

An underlying goal for the Hannas farm was to improve the overall farm system in a sustainable way. They have undertaken an intensive farm development programme involving subdivision, fertiliser, pastoral renewal and genetic improvement of their animals. Underlying this has been their monitor programme which includes measuring weight gain, soil temperature, rainfall, pasture growth, pasture cover, pregnancy scanning and faecal egg counts.

Part of being the central study farm involved the classification of the farm into different land groups based on geology, slope, soil type and soil fertility (Table 1). These were analysed differently for fertiliser and lime requirements, stocking type and breeding/ finishing differentiation. This information has also become a guide for land and environmental management and sustainable farming practices.

Table 1 Land classification and area in pasture on the Hanna farm at Mahoenui in the King Country.

\begin{tabular}{lcc}
\hline Description & Slope & $\begin{array}{c}\text { Area } \\
\text { (ha) }\end{array}$ \\
\hline Papa hills & Steep & 51 \\
Ash hills & Steep & 120 \\
Ash hills & Rolling & 55 \\
Clay hills & Rolling & 61 \\
Alluvial and ash flats & Flat & 163 \\
Total & - & 450 \\
\hline
\end{tabular}

To increase lamb production and breeding ewe efficiency, the Hannas started introducing Finnish Landrace (Finn) genes into their flock in 1995. Their flock now comprises a $1 / 2$ Finn $1 / 2$ Romney base but recently, a Texel component has been introduced.
The Hannas were initially unwilling to increase the size of their bull beef component until they had completed electric fence subdivision and had taken out areas of land they considered unsuitable for such a stock class. They have endeavoured to optimise the use of each land class, recognising the limitations and potential of each soil type.

The farm stock type and ratios are a direct reflection of analysis undertaken during the study group process. The main changes in stock numbers and policies over the last 5 years have been a slight reduction in ewe and breeding cows numbers to make way for more finishing bulls (Table 2). The ratio of breeding to finishing livestock has not changed dramatically, however cattle have increased from 51 to $57 \%$ over this time. Liveweight/ha wintered has reduced as cow numbers have declined.

\section{Results}

The increased subdivision and pasture growth on the rolling hill country has increased the ability to feed and finish livestock in these areas. In combination with the cross-breeding programme this has meant that greater production has been achieved from fewer ewes. Furthermore, better pasture utilisation and performance has been possible in the steeper areas of the farm.

During the final 2 years (1997 and 1998) of the farm study group project, the production increase across all group members (30) averaged 7\%, with an economic farm surplus increase of $12 \%$. Improvements on the Hannas' farm however, were greater, gross income has doubled in the last 5 years whereas cash surplus has increased by $486 \%$ (Table 3 ). Although a fair proportion of this can be attributed to external factors

Table 2 The change in stock numbers, sheep to cattle ratios, and start of lambing and calving dates on the Hanna farm.

\begin{tabular}{|c|c|c|c|c|c|c|}
\hline Stock class & $30 / 6 / 96$ & $30 / 6 / 97$ & $30 / 6 / 98$ & $30 / 6 / 99$ & $30 / 6 / 00$ & $30 / 6 / 01$ \\
\hline MA ewes & 1970 & 1850 & 1970 & 1970 & 1800 & 1790 \\
\hline Ewe hoggets & 680 & 960 & 940 & 670 & 540 & 575 \\
\hline Rams & 28 & 26 & 30 & 28 & 28 & 28 \\
\hline MA cows/hfrs (VIC)* & 164 & 196 & 209 & 169 & 132 & 139 \\
\hline R2-year heifers & 15 & - & - & - & - & - \\
\hline R1-year heifers & 65 & 120 & 50 & - & 45 & - \\
\hline R2-year steers & 68 & 5 & - & 47 & - & - \\
\hline R1-year steers & 5 & - & - & - & - & - \\
\hline R2-year bulls & 52 & - & - & 46 & 95 & 100 \\
\hline R1-year bulls & 142 & 171 & 260 & 240 & 275 & 325 \\
\hline Breeding bulls & 5 & 5 & 5 & 5 & 5 & 4 \\
\hline Sheep: Cattle ratio & $49: 51$ & $53: 47$ & $52: 48$ & $48: 52$ & $44: 56$ & $43: 57$ \\
\hline Breeding: Finishing ratio & 57.43 & $59: 41$ & $61: 39$ & $67: 33$ & $59: 41$ & $58: 42$ \\
\hline Liveweight /ha. & 786 & 736 & 794 & 790 & 770 & 760 \\
\hline Calving date & $20 / 9$ & $20 / 9$ & $25 / 9$ & $1 / 10$ & $1 / 10$ & $1 / 10$ \\
\hline
\end{tabular}

*VIC = vetted in-calf 
such as exchange rates, expenditure has only increased by $28 \%$ and the best indicator of all, product sold (meat and wool), has increased by $35 \%$ in this 5 -year period. The return per $\mathrm{kg}$ of product sold has increased by $318 \%$ from $\$ 0.55$ to $\$ 1.75$ (Table 3 ). These gains can be directly attributed to the decisions made in earlier years with regard to stock policies and investments in genetics and technologies such as computer software for decision support and data management. Lamb numbers have increased owing to the influence of the Finn genetics (Table 4). As bull numbers have increased, average weight has not suffered as a result of increased stocking rate (Table 5). In 1997, the average stocking rate on the bull unit was 2.5 per ha and by 2001 this had increased to 3 per ha.

Opening liveweight/ha is a Figure that is often quoted, for the efficiency of production but the measure of total product sold (less purchases) is a better measure of the efficiency of any farm operation. The amount of product sold in relation to liveweight on 1 July has increased from 27 to $43 \%$ over the past 5 years (Table 6 ).

At the end of the farm study group project in 1998, the Hannas set out a goal for the next 3 years to lift farm production to $385 \mathrm{~kg}$ of product (meat and wool)/ha. Results to date show that by June 302001 , they will have achieved $324 \mathrm{~kg} / \mathrm{ha}$. They still consider their original aim is attainable and are constantly reviewing ratios of livestock classes and stocking rates to achieve their goal on a sustainable basis. What has developed out of this process is a good understanding of next season's production. Pregnancy scanning of ewes and pre-winter liveweight for cattle are good indicators. By using their database of previous liveweight, pasture cover and pasture growth history, they can make relatively accurate predictions for future stock supply times and product weight range.

During the past 12 months, the Hannas have supplied a proportion of their prime lambs on futures contracts and have found this to be very rewarding. During the supply period, they received an estimated $\$ 4 /$ head premium over non-contracted lambs. More importantly, they were able to grow these lambs out to higher weights than they would otherwise have done. The Hannas are planning to make more use of future supply contracts this year; some results from cattle contract sales during January and February this year were outstanding, with premiums of $60 \mathrm{c} / \mathrm{kg}$ being received. Other farmers with futures contracts have been equally pleased with the flexibility of being able to grow their stock out and the prices received. Contracts are normally for a 1- to 2-month period, with pricing
Table 4 Changes in scanning percentage (lambs scanned over ewes mated) and the number of lambs surviving to sale (or retained) on the Hanna farm.

\begin{tabular}{lccccc}
\hline & $1995 / 96$ & $1997 / 98$ & $1998 / 99$ & $1999 / 00$ & $2000 / 01$ \\
\hline Scanning \% & 128 & 148 & 158 & 164 & 176 \\
Lambs produced & 2210 & 2235 & 2305 & 2626 & 2620 \\
\hline
\end{tabular}

Table 5 Change in bull beef cattle numbers and the change in average carcass weight $(\mathrm{kg})$ achieved on the Hanna farm.

\begin{tabular}{lccccc}
\hline & $1995 / 96$ & $1997 / 98$ & $1998 / 99$ & $1999 / 00$ & $2000 / 01$ \\
\hline Number of bulls sold & 84 & 170 & 285 & 280 & 360 \\
Mean carcass wt & 270 & 306 & 268 & 289 & 310 \\
\hline
\end{tabular}

Table 6 Changes to liveweight per hectare, product sales $(\mathrm{kg} /$ ha) and sales as a percentage of opening liveweight/ha on the Hanna farm.

\begin{tabular}{|c|c|c|c|c|c|}
\hline & $1995 / 96$ & 1997/98 & $1998 / 99$ & $1999 / 0 C$ & $2000 / 01$ \\
\hline 1 June LWT & 786 & 794 & 790 & 770 & 760 \\
\hline Produce sales & 211 & 289 & 294 & 301 & 324 \\
\hline $\begin{array}{l}\text { Sales as a\% } \\
\text { of opening LWT }\end{array}$ & 27 & 37 & 38 & 39 & 43 \\
\hline
\end{tabular}

adjustments across a range of grades. The time (within a week) of supply and the number being supplied, are fixed parameters, and penalties for not meeting these are enforced. The importance of accurate monitoring, planning, and creating a reputation as a reliable, accurate supplier will become very important in negotiating contracts.

Most meat companies are now offering future supply contracts. This is a strong signal as to the way they want to procure a large portion of their livestock supply in the future. There will be good economic benefits for farmers who are prepared to put the infrastructure in place in terms of monitoring and planning, so as to supply a large portion of their livestock this way.

Winning the 1999 Waikato Farm Environment award has had a major influence on the Hannas' farming objectives. They believe that being able to demonstrate sustainable farming practices will rapidly become an 
entry requirement for high value markets and contracts. Since they moved onto their farm, the Hannas have retired and planted erosion-prone areas and fenced off the banks of the Awakino River. They have an ongoing programme to plant for shelter, shade and beautification and are members of the Mahoenui Land Care Group. In addition to the 450 ha in pasture, the Hannas have 70 ha in fenced off waterways, retired areas and woodlots. A further 350 ha of their original farm is now in native forest reserve.

\section{Conclusions}

- The Hannas have developed farm-monitoring protocols to improve the way they farm.

- These protocols have allowed them to enter into fixed price contracts.

- They have identified seasonal liveweight and weight gain patterns, which along with feed supply information, are the key drivers required to meet these contracts.

- Their experience with the farm study group programme and their ability to integrate monitoring information into decision-making has meant they are in control of their farm and not at the mercy of the market place.

\section{ACKNOWLEDGEMENTS}

Technology New Zealand, Ravensdown Fertiliser Ltd and Wrightsons Rural Supplies are gratefully acknowledged for their support of the farm study group project.

\section{REFERENCES}

Marshall, P.R.; McCall, D.G.; Johns, K.L. 1991. Stockpol: A decision support model for livestock farms. Proceedings of the New Zealand Grassland Association 53: 137-140.

Sheath, G.W.; Webby, R.W.; Keeling, P.; Thomson, R.D.; Page, C.R.; Burton, G.T. 1999. The results and success factors of nine group farm monitoring programmes. Proceedings of the New Zealand Society of Animal Production 59: 87-90.

Webby, R.W.; Paine, M.S. 1997. Farmer groups: a measure of their effectiveness. Proceedings of the New Zealand Society of Animal Production 57: 109-111.

Webby, R.W.; Sheath, G.W. 1991. Group monitoring, a basis for decision making and technology transfer on sheep and beef farms. Proceedings of the New Zealand Grassland Association 53: 13-16. 